\title{
COMMENT
}

\section{CHAPTER X TRUSTEE ADOPTION OF EXECUTORY CONTRACTS: THE BANKRUPTCY ACT SPEAKS THROUGH ITS SILENCE}

Under the present federal bankruptcy statute, a company whose indebtedness has placed it in financial difficulty can elect to avoid straight bankruptcy, and consequent corporate dismemberment, by attempting a reorganization. Chapter $\mathrm{X}$ of the Bankruptcy Act ${ }^{1}$ provides judicial machinery for the reorganization of the large, publicly held corporation with a complex debt structure. ${ }^{2}$

A chapter $X$ proceeding can be initiated voluntarily, or by the corporation's creditors, ${ }^{3}$ by filing a petition in district court stating that the corporation is insolvent or unable to pay its debts as they mature. ${ }^{4}$ Upon court approval of the petition, the district judge must appoint a trustee if liabilities exceed $\$ 250,000$, while such appointment is discretionary if liabilities are less than that sum. ${ }^{5}$ The trustee appointed must be "disinterested"; ${ }^{6}$ he is to have no financial connection with, or interest in, the debtor corporation. $\mathrm{He}$ is usually experienced in the debtor's field of business. The trustee's order of appointment vests him with title to the debtor's property ${ }^{7}$ and gives him authority to perform administrative and management functions. ${ }^{8}$

152 Stat. 883 (1938), as amended, 11 U.S.C. $\$ \$ 501-676$ (1964).

2 Chapter XI, 52 Stat. 905 (1938), as amended, 11 U.S.C. $\$ \$ 701-799$ (1964), also covers corporations, but is intended primarily to provide a simple method for the composition or extension of unsecured indebtedness by an individual or by a small corporation with few shareholders. A chapter XI arrangement is always voluntary. For a good discussion of the differences between these two chapters as applied to a reorganization which fell somewhere between the two, see Grayson-Robinson Stores, Inc. v. SEC, 320 F.2d 940 (2d Cir. 1963), and authorities cited id. at 948 n.10.

3 Bankruptcy Act $\$ 126,52$ Stat. 885 (1938), 11 U.S.C. $\$ 526$ (1964). Three or more creditors with aggregate claims of $\$ 5,000$ or more are required.

4 Bankruptcy Act $\$ 130,52$ Stat. 886 (1938), 11 U.S.C. $\$ 530$ (1964).

5 Bankruptcy Act $\$ 156,52$ Stat. 888 (1938), 11 U.S.C. $\$ 556$ (1964).

6 Ibid. For the act's definition of who is not disinterested, see $\S 158,52$ Stat. $\$ 88$ (1938), 11 U.S.C. $\$ 558$ (1964).

7 Bankruptcy Act $\$ 186,52$ Stat. 892 (1938), 11 U.S.C. §586 (1964). A debtor in possession has the same title under $\$ 188,52$ Stat. 892 (1938), 11 U..S.C. $\$ 588$ (1964).

8 Bankruptcy Act $\S 189,52$ Stat. 892 (1938), 11 U.S.C. $\$ 589$ (1964). One commentator remarks:

Broadly speaking, the purpose of this order is to permit a trustee to operate the business of the debtor in substantially the manner in which it had been operated by the debtor itself zuithont constant resort to the conrt . . . for instructions on relatively unimportant points. The trustee will, however, if well advised, request instructions [from the judge under whose authority the proceedings are held] from time to time where any fundanental change of business or financial policy is involved.

Israels, Some Problems of Policy and Procedure in the Conduct of Reorganization Proceedings, 89 U. PA. L. REv. 63, 72 (1940). (Emphasis added.)

Almost as a corollary, the trustee is held to a high degree of responsibility: he must exercise the care and control that a man of ordinary prudence would exercise 
The order of appointment can be quite detailed in its instructions to the trustee, but its general thrust will be to empower the trustee to operate the business profitably, without prejudicing any creditor or shareholder rights.

In order to enable the debtor to get back on its feet, the reorganization court's approval of the petition acts as a stay of any proceedings to enforce any lien or claims against the debtor's property. ${ }^{9}$ Given this breathing space, the trustee examines the debtor corporation. ${ }^{10}$ If he determines that a successful reorganization can be achieved, ${ }^{11}$ he begins to streamline the debtor's business. The court is specifically empowered by the act to discard unprofitable executory contracts and leases of real property. Section 116(1) provides:

Upon the approval of a petition, the judge may . . . (1) permit the rejection of executory contracts of the debtor, except contracts in the public authority, upon notice to the parties to such contracts and to such other parties in interest as the judge may designate. ${ }^{12}$

This section requires the trustee to petition the judge before any contract or lease may be rejected, ${ }^{13}$ thereby protecting the in-

over his own property. E.g., In re Schott Brewing Co., 40 F. Supp. 706 (S.D. Ill. 1941). And consider the following:

The controlling fact... is that a reorganization trustee operates the properties for the benefit of the private parties concerned with a view of making the maximum profit from them. He stands in the position of the employer ....

Finletter, Bankruptcy Reorganization 205 (1939).

9 Bankruptcy Act $\$ 148,52$ Stat. 888 (1938), 11 U.S.C. $\$ 548$ (1964).

$10 \mathrm{An}$ investigation of the debtor's past management and general financial condition may proceed under $\$ 167$ of the Bankruptcy Act. 52 Stat. 890 (1938), 11 U.S.C. $\$ 567$ (1964).

11 Bankruptcy Act $\S 167(5), 52$ Stat. 890 (1938), 11 U.S.C. $\$ 567(5)$ (1964) :

The trustee upon his appointment and qualification ... (5) shall, at the earliest date practicable, prepare and submit a brief statement of his investigation of the property, liabilities, and financial condition of the debtor, the operation of its business and the desirability of the continuance thereof, in such form and manner as the judge may direct . . . .

Unlike chapter XI, chapter X has no requirement that the debtor's initial petition be accompanied by a statement of its executory contracts. See $\$ 324,52$ Stat. 907 (1938), as amended, 11 U.S.C. $\$ 724$ (1964). Compare note 69 infra.

1252 Stat. 885 (1938), as amended, 11 U.S.C. $\$ 516(1)$ (1964). An unexpired lease of real property is an executory contract. Section 106(7), 52 Stat. 883 (1938), 11 U.S.C. $\$ 506(7)$ (1964). This study will not consider whether the contract in question is an executory contract within the meaning of $\$ 116(1)$ or $\$ 216(4)$, see text accompanying note 22 infra, but will assume the contract's executory nature in every case. Compare Silverstein, Rejection of Executory Contracts in Bankruptcy and Reorganization, 31 U. CHI. L. REv. 467, 474-83 (1964). And insofar as this study is limited to a study of adoption procedure, no distinction has been drawn between debtor as lessor or as lessee. Compare $i d$. at 484.

13 Both In re Childs Co., 64 F. Supp. 282 (S.D.N.Y.), aff'd, 146 F.2d 592 (2d Cir. 1944), and the history of this section as elucidated herein should make it clear that $\S 116$ (1) is at the very least to be interpreted in the same way as was $\S 77 \mathrm{~B}$ (c) (5), requiring court approval for rejection. See note 37 infra.

The requirements of the comparable straight bankruptcy procedure under $\$ 70(\mathrm{~b})$ are inapplicable to a chapter $\mathrm{X}$ proceeding. See note 58 infra and accompanying text. 
terests of the other party to the contract by requiring judicial consideration. ${ }^{14}$

Any party whose contract with the debtor has been rejected pursuant to section $116(1)$ is deemed a general creditor under the provisions of section 202, , $^{15}$ and is allowed to file a claim for damages which is to be paid pro rata from the assets available to unsecured creditors under the reorganization plan.

The maintenance of the debtor's business operations will, of course, require the trustee to continue many contractual obligations; yet chapter $\mathrm{X}$ fails to set out any required statutory procedure for trustee adoption or affirmance of the debtor's executory contracts.

During the time the trustee is streamlining the debtor's business, he is drafting a "reorganization plan." 16 This plan is a legal document rearranging creditors' and shareholders' rights in order both to make the business capable of showing a profit, and to gain the new capital needed to make the business self-sufficient. The plan is submitted to the court within the judicially established time limit, ${ }^{17}$ which can be, and often is, extended upon petition by the trustee. ${ }^{18}$ The time required to draw up a feasible plan varies from case to case-several months, ${ }^{19}$ two years, ${ }^{20}$ even twenty-nine years in one instance. ${ }^{21}$ Complexity of the corporation's capital structure and its financial arrangements obviously affect the length of time needed.

14 Court approval of the rejection of executory contracts necessarily results in an increase in the time and consequent expense of administration, in part through the expense of the hearings themselves, which are charged to the estate as an expense of administration under $\$ 64(a)(1)$. 52 Stat. 874 (1938), as amended, 11 U.S.C. $\S 104(a)(1)$ (1964). Justification for this result is suggested in note 56 infra.

1552 Stat. 893 (1938), 11 U.S.C. $\$ 602$ (1964), construed in 120 Wall Associates v. Schilling, 266 F.2d 548 (2d Cir. 1959) ; City Bank Farmers Trust Co. v. Irving Trust Co., 299 U.S. 433 (1937) (interpreting \$77B(b) (10), the immediate precursor of $\$ 202)$.

${ }^{16}$ The extent of the plan's provisions is encompassed in $\$ 216.52$ Stat. 895 (1938), 11 U.S.C. $\$ 616$ (1964).

17 Section 169, 52 Stat. 890 (1938), 11 U.S.C. $\$ 569$ (1964).

18 Section 119, 52 Stat. 885 (1938), 11 U.S.C. \$519 (1964); cf. In re Roger Williams Bldg. Corp., 99 F.2d 212, 217 (7th Cir. 1938), cert. denied, 307 U.S. 635 (1939) (dictum). See Hotz v. Federal Reserve Bank, 108 F.2d 216, 220 8th Cir. 1939):

In corporate reorganization proceedings a bankruptcy court can review purely administrative orders entered in receivership proceedings involving the corporation, and can make such orders as are deemed equitable for the protection of obligations incurred by a receiver or prior trustee.

19 For an interesting study of one company's post-war reorganization, see Kaplan, Lyne \& Hurley, The Reorganization of the Walthann Watch Company: $a$ Clinical Study, 64 HARV. L. REV. 1262 (1951) (two reorganizations of nine and four months).

20 Texas Importing Co. v. Banco Popular de Puerto Rico, 360 F.2d 582 (5th Cir. 1966). Litigation added two years to the elapsed time. The petition was filed June 22, 1962. Id. at 583. The order approving the amended plan was filed August 5, 1964. Record, p. 79, Texas Importing Co. v. Banco Popular de Puerto Rico, supra.

21 Pines, The Inland Gas Corporation Case: An Epic of Corporate Reorganization, 47. A.B.A.J. 1163 (1961). The reorganization-beginning with appointment of receiver on December 1,1930 and ending with denial of certiorari on the final plan on June $6,1960-$ spanned equity receivership, $\$ 77 \mathrm{~B}$ and chapter $X$. 
The plan may also provide for the rejection of executory contracts. Under section 216(4):

A plan of reorganization under this chapter-(4) may provide for the rejection of any executory contract except contracts in the public authority. ${ }^{22}$

When a contract or lease is rejected, section 202 grants the injured party the same remedy he would have if the contract had been rejected prior to the plan. Like section $116(1)$, this section is silent on the procedure for trustee adoption of executory contracts, even though it is well settled that the trustee is expected to adopt those contracts which he considers profitable as well as those leases which he considers valuable assets. ${ }^{23}$

The trustee submits the plan to the district court judge for his approval, which is granted if the plan is "fair, equitable and feasible" and conforms to statutory guidelines. ${ }^{24}$ The plan is then sent to the creditors for their approval or objections (creditor suggestions for the plan may be entertained by the trustee under section $167(6)) .^{25}$ This Comment will explore the problems raised by the statutory silence on the procedure for adoption of contracts and will treat the more specific problem of the extent to which pre-plan adoption should bind the court at the time of plan confirmation.

Under equity practice existing prior to the first federal legislation governing corporate reorganization, a receiver ${ }^{26}$ was appointed to direct the affairs of a failing company upon the filing of a creditor's bill. $^{27}$ The receiver was allowed a "reasonable time" to decide about

2252 Stat. 895 (1938), 11 U.S.C. $\$ 616(4)$ (1964).

23 There is authority for the proposition that the trustee has a duty to affirm those contracts which are an asset to the debtor. Butterworth v. Degnon Contracting Co., 214 Fed. 772, 773 (2d Cir. 1914) (receiver); Harrigan v. Gilchrist, 121 Wis. 127, 352-53, 99 N.W. 909, 978 (1904). See Note, Abandonnent of Assets by a Trustee in Bankmptcy, 53 Colum. L. Rev. 415, 418 (1953).

24 Section 174, 52 Stat. 891 (1938), 11 U..S.C. $\$ 574$ (1964). There may be more than one plan submitted since creditors may tender plans under $\$ \S 167(6)$ and 169. 52 Stat. 890 (1938), 11 U.S.C. $\$ \$ 567(6), 569$ (1964). The statutory guidelines to be applied to any plan sought to be submitted to creditors are found in $\$ 216$. 52 Stat. 895 (1938), 11 U.S.C. $\$ 616$ (1964). The "fair and equitable" doctrine was developed in Northern Pac. Ry. v. Boyd, 228 U.S. 482 (1913); Case v. Los Angeles Lumber Prods. Co., 308 U.S. 106 (1939); and Marine Harbor Properties, Inc. v. Manufacturers Trust Co., 317 U.S. 78 (1942). It is an extensive subject and beyond the scope of this Comment; the doctrine requires each class of creditors and shareholders to receive the value of its interest in the debtor's assets before the next rank below can participate. Thus the lowest rank, the common stockholders, retains no interest whatever unless every superior class is compensated in full.

2552 Stat. 890 (1938), 11 U.S.C. $\$ 567(6)$ (1964). The plan must be accepted by two-thirds of the creditors in amount and one-haif of the creditors in number. Section 179, 52 Stat. 892 (1938), 11 U.S.C. $\$ 579$ (1964).

${ }_{26}$ Although there are differences-e.g., the receiver did not get title to the debtor's assets - the receiver roughly corresponds to the present trustee in reorganization. In re Chase Commissary Corp., 11 F. Supp. 288, 289 (S.D.N.Y. 1935).

27 The receivership was theoretically adverse litigation, though the debtor usually prevailed upon a friendly creditor to file the bill to which the debtor would willingly submit. See Friendly, Some Comments on the Corporate Reorganizations Act, 48 HARV. L. REv. 39, 41 (1934). For a general discussion of equity receivership, see 6 Collier, BaNKRUPTCY $\uparrow 0.04$ (14th ed. Moore 1965) [hereinafter cited as CollIER]. 
the disposition of any executory contracts; ${ }^{28}$ during this time, and throughout the receiver's administration, the equity court stayed any creditor's actions against the debtor. The length of the "reasonable time" varied from case to case, but usually ran for about six months from the time of the receiver's appointment. ${ }^{29}$ Once the receiver determined that it was advantageous for the debtor to insist upon performance of any contract or the continuance of any lease, ${ }^{30}$ he would notify the other contracting party of his intention to perform his part of the contract and to insist upon counter-performance. ${ }^{31}$ It was possible, however, for a receiver to be held to have adopted a contract through inaction or conduct inconsistent with its rejection. ${ }^{32}$

In order to correct abuse of the receivership procedure, ${ }^{33}$ and

28 Dushane v. Beall, 161 U.S. 513, 515 (1896); United States Trust Co. v. Wabash W. Ry., 150 U.S. 287, 299-300 (1893); In re Mallow Hotel Corp., 17 F. Supp. 872, 873 (M.D. Pa. 1937) ; Pacific W. Oil Co. v. McDuffie, 69 F.2d 208, 213 (9th Cir.) (by implication), cert. denied, 293 U.S. 568 (1934).

29 See authorities cited note 28 supra.

$30 \mathrm{It}$ is assumed throughout this Comment that, unless otherwise noted, the contract or lease to be adopted is one in which the receiver or trustee can insist upon counterperformance-i.e., that there are no provisions in the lease which give the lessor or solvent party the right to terminate the contractual relationship upon an adjudication of bankruptcy, insolvency, devolution of title, etc. Compare the straight bankruptcy provisions of $\$ 70 \mathrm{~b}, 52$ Stat. 880 (1930), as amended, 11 U.S.C. $\$ 110$ (b)

(1964) which provide:

Unless a lease of real property expressly otherwise provides, a rejection of

the lease or of any covenant therein by the trustee of the lessor does not deprive the lessee of his estate. A general covenant or condition in a lease that it shall not be assigned shall not be construed to prevent the trustee from assuming the same at his election and subsequently assigning the same; but an express covenant that an assignment by operation of law or the bankruptcy of a specified party thereto or of either party shall terminate the lease or give the other party an election to terminate the same is enforceable.

By the force of $\$ 102,52$ Stat. 883 (1938), 11 U.S.C. $\$ 502$ (1964), this provision is applicable to a chapter $X$ reorganization. Finn v. Meighan, 325 U.S. 300, 302-03 (1945).

31 For a discussion of the means through which a receiver could effectuate an adoption, or under what facts a court would find adoption, see Clark, Foley \& Shaw, Adoption and Rejection of Contracts and Leases by Receivers, 46 HARv. L. Rev. 1111, 1122-23 (1933). See text accompanying notes 73-74, 76 infra.

32 In re Mallow Hotel Corp., 17 F. Supp. 872 (M.D. Pa. 1937), dealt with receivers who had never expressly adopted or attempted to reject leases of hotel property, but who had used the premises for five years. The court held that "this occupancy was far in excess of a reasonable time within which to elect to adopt or reject the leases." The court cited another equity case, Menke v. Willcox, 275 Fed. 57, 59 (S.D.N.Y. 1921), which held :

In order to be bound, they must positively indicate their intention to take . . .

[the lease] over. . . . That intention may be indicated by remaining in

enjoyment of the asset without dissent. . . But in such cases it is only

because an assent may in fact be so implied.

Id. at 873. The court also cited Thomas v. Cincinnati, N.O. \& T.P. Ry., 77 Fed. 667, 670 (S.D. Ohio 1896), which held that a receiver had "elected" to assume a lease because he had remained in possession of the premises for three and one-half years.

33 Under receivership practice no plan was drawn up by the receiver for court examination as is required under the present chapter $X$. Because receiverships were in theory adverse litigation-the debtor was ostensibly dragged into court by his creditors-creditors' "protective committees" representing different classes of creditor interest were formed to bid for the assets of the debtor corporation pursuant to a "plan" of purchase submitted by a majority of the creditors. Most often the "plan" provided for little more than the issuance of stock in the reorganized corporation 
to eliminate the problems created by ancillary receiverships, reform of equity receiverships was begun in the early thirties, prompted by the then severe economic conditions. Railroad reorganizations had been placed under federal court control by section 77 ;4 $^{44}$ then, in 1934, Congress amended the Bankruptcy Act by enacting section $77 \mathrm{~B}^{35}$ giving federal courts jurisdiction over, and supervision of, the reorganization of business corporations, other than railroads already covered by section 77 .

Section 77B was passed to insure continuance of essentially the same objectives that had been sought in equity receiverships. In a report of the Judiciary Committee of the House of Representatives on the original section $77 \mathrm{~B}$, it was said:

While the bill was framed with due regard for the present and immediate prospective economic conditions, it is believed that an expansion of the opportunity for amicable adjustment by debtor and creditors, under the supervision and protection of the bankruptcy courts, and for holding the property of the debtor intact with its operation disturbed as little as practicable such as is provided in this bill, will prove itself to be of permanently helpful assistance both to distressed corporations and in line with the public interest. ${ }^{36}$

Although the basic objectives of the statute paralleled those of equity receiverships, reorganization trustees' powers were restricted: rejection of executory contracts soon became the specific province of the reorganization court. $^{37}$

to the purchasing creditors in proportion to their claims. Since these majority creditors already had large claims outstanding against the debtor, they could purchase the debtor with only the cash needed to satisfy the dissident creditors and shareholders; they could easily outbid any other potential buyers, and attempts by the courts to fix prices did not succeed. The minority interests had to be content with the share allocated them by the majority because of their weak bargaining position; the possibility of prejudice to their rights is apparent. See Jackson, Receivership and Bankruptcy Proceedings in United States Courts, SEN. Doc. No. 268, 74th Cong., $2 \mathrm{~d}$ Sess. 26 (1936); Friendly, supra note 27; Moore, Reorganizations Under Chapter $X, 35$ ReF. J. 105, 108-09 (1961). See generally 6 Collmer 10.04 ; Payne, The General Administration of Equity Receiverships of Corporations, 31 YALE L.J. 685 (1922); Rosenberg, $A$ New Schente of Reorganization, 17 Colum. L. Rev. 523 (1917).

3447 Stat. 1474 (1933), as amended, 11 U.S.C. \$205 (1964).

3548 Stat. 912 (1934). The passage of the bill seems also to have been Congress' response to Supreme Court dicta which cast doubt upon the validity of the consent equity receivership. See Friendly, supra note 27, at 41-45.

36 Quoted in In re Realty Associates Sec. Corp., 54 F. Supp. 787, 788 n.1 (E.D. N.Y. 1944), aff'd, 156 F.2d 480 (2d Cir. 1946).

37 Section $77 B$ (c) (5) read in part: "[T]he judge . . . (5) may direct the rejection of contracts of the debtor executory in whole or in part." 48 Stat. 916 (1934). Section 77B(b) (6) read: "A plan of reorganization within the meaning of this section. . (6) may reject contracts of the debtor which are executory in whole or in part, including unexpired leases except contracts in the public authority." 48 Stat. 914 (1934).

Section $77 \mathrm{~B}$ (c) (5), dealing with pre-plan rejection, was interpreted to require court approval of any rejection, and the power to reject executory contracts was 
Section $77 \mathrm{~B}$ is the immediate predecessor of chapter $\mathrm{X}$ of the Bankruptcy Act, passed with the Chandler Act revisions of 1938. No changes relevant to this study were made in the provisions empowering court rejection of executory contracts. ${ }^{38}$

Legislative comments accompanying the Chandler Act indicate an intention to continue, and clarify, reorganization practice as it had existed under section $77 \mathrm{~B} .^{39}$ An effort was made, however, to integrate the Chandler Act revisions with other provisions of the Bankruptcy Act and, most importantly, with past equity practice. ${ }^{40}$ Section 115 of chapter $X$ provides that the reorganization court may

exercise all the powers, not inconsistent with the provisions of this chapter, which a court of the United States would

effectively lodged in the court, not the trustee. In re Cheney Bros., 12 F. Supp. 605 (D. Conn. 1935). This case says nothing about trustee adoption:

Pozver to reject an executory contract under section $77 \mathrm{~B}(\mathrm{c})$ is not lodged in the debtor, nor in his trustee. Such power devolves exclusively upon the judge, and there is no restriction as to the agencies by which that power may be invoked. The exercise of such power is not necessarily predicated on a petition of the debtor or trustee. Any party in interest may invoke it.

Id. at 608. (Emphasis added.) But see Philadelphia Co. v. Dipple, 312 U.S. 168, 174 (1941). Misinterpretation of the Cheney case is a source of many headaches. See note 95 infra and accompanying text.

For concurrence in the view that $\$ 77 B$ leaves unaffected the procedures through which the trustee adopts contracts, and that practice under $\$ 77 \mathrm{~B}$ is substantively the same as under an equity receivership, at least as regards lessor rights, see $I_{n i}$ re Chase Commissary Corp., 11 F. Supp. 288, 289 (S.D.N.Y. 1935) :

The fact remains, however, that in substance the rights of the lessor and of the debtor's estate in custody of the court are the same as where an insolvent's assets are in [the] charge of a chancery receiver.

See also In re Schulte Retail Stores Corp., 22 F. Supp. 612, 615 (S.D.N.Y. 1937), and cases cited therein. Note that the same considerations apply to both trustee and debtor in possession. Ibid.

38 The sections treating rejection both during reorganization administration and in the plan are essentially the same in Chapter $X$ as they were under section 77B. The words "except contracts in the public authority" were added to $\$ 77 \mathrm{~B}(\mathrm{c})(5)$; that section became $\$ 116(1)$ of the Bankruptcy Act. 52 Stat. 885 (1938), as amended, 11 U.S.C. $\$ 516$ (1) (1964). Section 77B (b) (6) became, without change, $\$ 216(4)$ of the Bankruptcy Act. 52 Stat. 895 (1938), 11 U.S.C. $\$ 616(4)$ (1964). A sentence contained in $\$ 77 \mathrm{~B}(\mathrm{~b})$ became $\$ 202$ of the Bankruptcy Act. 52 Stat. 893 (1938), 11 U.S.C. $\$ 602$ (1964). See 6 CollmeR $\pi 0.07$, at 87, 89; S. REP. No. 1916, 75th Cong., $3 d$ Sess. 24, 32-34 (1938).

${ }^{39}$ See Hearings on H.R. 8046 Before the House Conmittee on the Judiciary, 75th Cong., 1st Sess. 5 (1937) (statement of Congressman Chandler) :

While corporate reorganization, as now proposed under the bill, to a great extent, rewrites the present act thereon [\$77B], nevertheless all valuable features have been retained, together with many changes proven necessary by experience. There will be noted . . the attempt, as far as possible, to remove the abuses of the present act, to speed $u p$ procedure, and to economize.

(Emphasis added.) For a general summary of the changes contemplated by the Chandler Act, see id. at 3-8.

40 Particular notice should be taken of the distinction so clearly drawn between reorganization and straight bankruptcy and the need for equitable flexibility in the former.

The proceedings under the orthodox bankruptcy act resulted in the destruction of the enterprise and its liquidation. This is essentially different from reorganization, which preserves the enterprise by readjusting its capital structure to its impaired financial condition. The former procedure is adapted to standardized conditions, and experience has proved the desirability of 
have if it had appointed a receiver in equity of the property of the debtor . . . ${ }^{41}$

The net result of this legislative activity is that district courts now have specific authority to reject executory contracts during the estate's administration (section $116(1)$ ), and in the reorganization plan (section 216(4)). Through section 115 the court has been granted the equitable powers of the older equity receiver courts to fashion orders and decrees consistent with the provisions of the Bankruptcy Act. It is well established that a chapter X court should follow equitable principles just as its statutory and chancery antecedents did. ${ }^{42}$

rigidity of procedure, whereas reorganization procedure must be adapted to varied situations necessitating flexibility. Most of the provisions and machinery having to do with liquidation are consequently entirely inappropriate to the reorganization.

Hearings on H.R. 8046 Before the Subcommittee on the Revision of the National Bankruptcy Act of the Senate Committee on the Judiciary, 75th Cong., 2d Sess. 37 (1938) [hereinafter cited as Senate Hearings].

In straight bankruptcy you have the same result in every case. The enterprise is destroyed, the assets converted into cash, the expenses are taken out, and the balance is distributed among the creditors. It may be that in bankruptcy some concerns are sold as a going concern. Usually business is stopped and the assets are sent to the auctioneer. Every corporation is treated the same way. A rigid inflexible procedure is consequently appropriate. Not so in reorganization. No two corporations are alike. No two capital structures are the same. No two plans are alike. Consequently, you must have a procedure flexible enough to meet the circumstances of each particular case.

Id. at 92 .

The drawn-out administration of receivership organizations had produced exorbitant legal fees which nearly deprived the reorganization of any possible chance for success in developing profitable operations. Senate Hearings 127-28; Swaine, Corporate Reorganization Under the Federal Bankruptcy Power, 19 VA. I. REv. 317 (1933). See Douglas \& Frank, Landlords' Clains in Reorganizations, 42 Y ALE L.J. 1003, 1046 (1933) :

To delay the ultimate distribution of the securities or the cash under the plan $\ldots$ is undesirable. Insofar as possible, administrative rules in this connection should be devised to accelerate the consummation of the plan. . . "[R]eceiverships are always expensive luxuries." The Chancellor should shape the decrees to meet the exigencies of the situation.

4152 Stat. 884 (1938), 11 U.S.C. $\$ 515$ (1964). For an indication of the expected scope of the power conferred on the district court by this section, see the debates on court power to reject a contract held by a public authority. Senate Hearings 171-213. And consider the following:

[T] here was enough protection in connection with contracts of that nature for these reasons; it was within the power of the court to permit or not to permit the rejection of a contract, and since the bankruptcy court was given all the jurisdiction of a court of equity, we believed that the bankruptcy court, acting as a court of equity, would have the power to refuse permission to reject a contract which was affected with a large public interest.

Id. at 198.

In connection with the need for shortened proceedings and simple procedure, in order to avoid debilitating administration expenses in the form of legal fees for counsel and court officers, consider the following:

Judges and lawyers should not be required to devote their time (and thus add delay and expense) to considering sections of the bankruptcy act which are not and should not be applicable to a flexible reorganization procedure. Id. at 37 .

The principles and precedents of equity are well established.

42 See, e.g., Vanston Bondholders Protective Comm. v. Green, 329 U.S. 156, 165 (1946); In re General Stores Corp., 164 F. Supp. 130, 137 (S.D.N.Y. 1958) ; aff'd 
In view of this history, the recent opinion of the Court of Appeals for the Fifth Circuit in Texas Importing Co. v. Banco Popular de Puerto Rico ${ }^{43}$ comes as somewhat of a surprise. The court allowed a trustee in a chapter $\mathrm{X}$ reorganization to reject a long-term lease pursuant to a plan of reorganization, despite the trustee's adoption of the lease in a letter written to the lessor nearly two years prior to the plan. Even more surprising are the reasons given by the court. The court held that, although chapter $\mathrm{X}$ does not mention the need for court approval of trustee adoption of executory contracts, judicial approval is required "by necessary implication." 44 It went further and rejected any application of the equitable considerations applied in equity receiverships, holding that, since adoption required judicial approval, which the trustee had failed to gain, trustee assumption could not be implied from his affirmative conduct. ${ }^{45}$ The court of appeals thus confirmed the plan, dismissing the lessor's objections thereto.

The court's unspoken assumption must have been that had a "binding" adoption occurred prior to the plan, the court would have been unable to permit rejection of the lease in the plan. In fact, the chapter of the Bankruptcy Act governing railroad reorganizations explicitly allows just such action: the court is granted power to reject executory contracts in the plan, regardless of whether they have been adopted by the trustee during his administration. ${ }^{46}$ This provision is omitted in section $77 \mathrm{~B}$ and its descendant-the present chapter X. Without this grant of court power to reject "regardless,"

in part and rev'd in part sub nom. Ruskin v. Griffiths, 269 F.2d 827 (2d Cir. 1959), cert. dentied, 361 U.S. 947 (1960); In re Schafer's Bakeries, 155 F. Supp. 902, 913 (E.D. Mich. 1957). See also Bank of Marin v. England, 385 U.S. 99 (1966) ; Pepper v. Litton, 308 U.S. 295, 304 (1939).

One case has seen the unity of statutory treatment as a function of equitable principles. In re Chicago Rapid Transit Co., 129 F.2d 1, 5 (7th Cir.), cert. denied, 317 U.S. 683 (1942) :

In determining the extent of bankruptcy power, it matters little whether we consider the precedents under the original act or under Sections 75,77 or $77 \mathrm{~B}$, for the intent and purport of all bankruptcy legislation, so far as the power to protect the estate is concerned, is largely declaratory of certain recognized equitable principles, namely: the power of a court of equity to

protect property in its custody.
Accord, In re Chase Commissary Corp., 11 F. Supp. 288, 289 (S.D.N.Y. 1935).

43360 F.2d 582 (5th Cir. 1966).

44 Id. at 584 .

45 Ibid.

46 The adoption of an executory contract or unexpired lease by the trustee or trustees of a debtor shall itot preclide a rejection of sich contract or lease in a plan of reorganization approved hereunder, and any claim resulting from such rejection shall not have priority over other claims against the debtor because such contract or lease had been previously adopted.

Section 77 (b), 49 Stat. 911 (1935), 11 U.S.C. $\$ 205$ (b) (1964). (Emphasis added.) The difference between the two statutes can be explained as a legislative policy decision on the necessity of sacrificing some creditor-lessor rights in a reorganization affecting the public need for continued railroad transportation, and the need to remove even minor impediments in the path of a successful reorganization. 
a pre-plan adoption would seem to prevent a court from permitting the rejection of the same contract in the plan. The Texas Importing court must have agreed. ${ }^{47}$

There are, unfortunately, no cases which clearly explain what effect pre-plan adoption has on the power of a court to reject a lease or contract in a plan pursuant to section 216(4). Further, there is no case which can be considered precedent for Texas Importing: ${ }^{48}$ it presented a problem of first impression in an area in which judicial interpretation of the applicable statutes had already been confused. ${ }^{49}$

Assuming the court was correct in its assumption that pre-plan adoption precludes rejection in the plan, the question is why court approval should be considered necessary for an adoption when chapter $\mathrm{X}$ does not require it. The reason offered by the Texas Importing court is that

if a trustee, without authorization by the court, can assume or adopt such a contract, or by conduct which would constitute an estoppel between private persons, could bar the court from exercising its statutory power to authorize the rejection of such a contract, then the power to determine that such a contract should or should not be rejected would be

47 It could hardly be supposed that a court faced with Texas Importing's facts would find that an "adoption" of a lease had occurred two years ago, and then permit its rejection in a plan absent statutory authority - the inequitable treatment in condoning unconscionable trustee action is patent. Thus, the only way the Texas Importing court could have permitted rejection of the lease in the plan was to find that the lease had never been effectively adopted. Possible reasons for the court's action are discussed at note 107 infra and accompanying text.

Collier gives hypothetical treatment to the problem of a plan's rejection of an already adopted executory contract, and decides that a court probably should not be permitted to reject in those circumstances, grounding his argument, however, on judicial approval as a requisite for effective adoption. 6 CoLLIER $\pi 3.24$, at 605-06. The Texas Importing court's continual citation to Collier indicates that it agreed with this analysis.

There is a reported case which suggests that prior adoption precludes rejection in the plan. In In re Davega Stores Corp., BANKR. L. REP. $\$ 60777$ (S.D.N.Y. 1963), a trustee renegotiated a lower rental of property occupied by the debtor on a twentyfive year lease while a chapter XI arrangement petition was pending; the new lease was approved by the court. Thereafter the petition was amended to comply with chapter $X$ requirements and the trustee sought to reject the lease. Judge Bonsal held that a contract once accepted could not thereafter be rejected. Cf. Grief Brothers Cooperage Co. v. Mullinux, 264 Fed. 391 (8th Cir. 1920).

48 The cases cited in note 47 supra are technically distinguishable in that adoption was effectuated through a court order in both instances. However, under the analysis presented in this Comment, it is submitted that an equitable adoption can properly be found, under some circumstances, which will operate to preclude the contract's later rejection. See Hotz v. Federal Reserve Bank, 108 F.2d 216, 219 (8th Cir. 1939) (prior express adoption by equity receiver held binding upon $\$ 77 \mathrm{~B}$ reorganization). Further, no case has been found where an express adoption was later repudiated by a chapter $\mathrm{X}$ court.

49 See, e.g., Wiemeyer v. Koch, 152 F.2d 230 (8th Cir. 1945) (court applied sixty-day limit of $\$ 70 \mathrm{~b}$ to a reorganization long after that portion of $\$ 70 \mathrm{~b}$ had been held inconsistent with and inapplicable to chapter X); In re Petrol Terminal Corp., 120 F. Supp. 867 (D. Md. 1954) (same). See also In re Public Ledger Inc., 63 F. Supp. 1008, 1016 (E.D. Pa. 1945), rev'd, 161 F.2d 762 (3d Cir. 1947) (confusing bankruptcy and reorganization). 
lodged in the trustee. We think no such result was intended. ${ }^{50}$

This statement runs counter to the legislative and common-law history of reorganization. It can be argued that just such a result was indeed intended; trustee decision-making was to be reviewed only when rejection was attempted. In addition to the statutory history discussed above, ${ }^{51}$ there are still other considerations which support a reading contrary to that of the court.

First, the appointed trustee must be "disinterested." 52 The obvious purpose of this provision is to gain not only the exercise of the objective business judgment needed to insure the operation of the debtor for its own profit, but to provide an impartial investigator of the debtor's affairs should mismanagement be discovered. ${ }^{53}$ Constant review of those decisions which merely continue past business dealings and keep operations intact is not imperative. In addition, one clear reason for requiring judicial approval of rejection is to guard against capricious discarding of contracts. An early attempt was made to use a chapter $\mathrm{X}$ proceeding as a means of disposing of burdensome labor contracts. ${ }^{54}$ That use of chapter $X$ was quickly denied by the courts, clearly illustrating the need for such a safeguard.

Further, there is a marked difference between chapter $\mathrm{X}$ provisions empowering a reorganization court to reject executory contracts ${ }^{55}$ and the comparable chapter VII provisions in straight bankruptcy. ${ }^{56}$ The

50360 F.2d at 584 .

51 See notes 26-42 supra and accompanying text.

52 See notes 5-6 supra and accompanying text. While it is true that this consideration is lacking in those cases involving liabilities of less than $\$ 250,000$ where the debtor has been left in possession, in the facts before the Texas Importing court this distinction was not relevant, especially in the view taken by this Comment's proposed alternate procedure.

The absence of a trustee should also not affect this analysis because the debtor usually remains in possession only in those cases where the business' financial difficulty stems from factors not wholly within the debtor's control and where his knowledge, judgment and integrity provide sufficient certainty of successful business rehabilitation. Further, the retention of the debtor in possession (as well as the appointment of the trustee) may be challenged by objecting parties. Section 162, 52 Stat. 889 (1938), 11 U.S.C. $\$ 562$ (1964). And finally, it has been argued that the debtor's interest in preserving the corporation's equity is sufficient interest to ensure the maintenance of a successful reorganization. Senate Hearings 39.

53 See note 8 supra.

54 In re Mamie Conti Gowns Inc., 12 F. Supp. 478, 480 (S.D.N.Y. 1935).

55 Section 116(1), 52 Stat. 885 (1938), 11 U.S.C. $\$ 516(1)$ (1964). For a good analysis of the power of rejection in the Bankruptcy Act, see Silverstein, Rejection of Executory Contracts in Bankruptcy and Reorganization, 31 U. CHI. L. REv. 467 (1964).

56 Section 70b, 52 Stat. 879 (1938), as amended, 11 U.S.C. $§ 110 \mathrm{~b}$ (1964), reads in part:

The trustee shall assume or reject an executory contract, including an unexpired lease of real property, within sixty days after the adjudication or within thirty days after the qualification of the trustee, whichever is later, but the court may for cause shown extend or reduce the time. Any such contract or lease not assumed or rejected within that time shall be deemed to be 
latter provisions require a trustee in bankruptcy to elect to adopt or reject the executory contracts held by the debtor within sixty days of adjudication, with a conclusive presumption of rejection if no action is taken or consideration given under the contract during that time. ${ }^{57}$ Both the time limit and presumption of rejection of chapter VII have been held to be inconsistent with and thus inapplicable to chapter $X .^{58}$ Juxtaposing these two sections highlights a distinction which needs further elaboration.

Adoption of an executory contract or lease in straight bankruptcy can easily mean the dissipation of whatever cash reserves are on hand, since the debtor's estate is thereby obligated to pay rent, or its consideration on the contract, from the date of petition filing. ${ }^{59}$ Payments under any adopted lease or contract in bankruptcy or reorganization become an "expense of administration" and must be satisfied

rejected. . . A trustee shall file, within sixty days after adjudication or within thirty days after he has qualified, whichever is later, . . . a statement under oath showing which, if any, of the contracts of the bankrupt are executory in whole or part, including unexpired leases of real property, and which, if any, have been rejected by the trustee.

This provision is also silent as to how a contract or lease is to be adopted. But see In re Forgee Metal Prods., Inc., 229 F.2d 799 (3d Cir. 1956), which held that the bankruptcy trustee had assumed a sales contract even though there was no formal expression by the trustee that he was assuming it, but merely his tacit approval of the referee's completion of the debtor's portion of the contract. Cf. In re Public Ledger Inc., 161 F.2d 762, 765 n.1 (3d Cir. 1947), discussed at note 77 infra.

Section $70 \mathrm{~b}$ keeps uncertainty and delay to a minimum by letting the bankrupt's creditors know where they stand very quickly; the notice of bankruptcy also informs creditors that they cannot expect too much in payment. Thus, it has been suggested that this provision permits the trustee to avoid rejecting many contracts upon which the debtor owes money for goods and services, thereby freeing the estate from a time-consuming administrative burden which would significantly add to the costs of administration. Silverstein, sipra note 55 , at 474 .

It is submitted that this analysis should be turned on its head and applied to chapter $\mathrm{X}$ : there is no need to require court approval to validate a trustee's adoption of many small executory contracts of obvious necessity to the business. To require approval for adoption, as has been done in Texas Importing, unnecessarily lengthens, and increases the costs of, administration of the estate. Cf. In re Avorn Dress Co., Inc., 78 F.2d 681, 683 (2d Cir. 1935). See note 14 sipra.

57 In the Matter of Gravure Paper \& Board Corp., 234 F.2d 928 (3d Cir. 1956) (trustee held to have abandoned leases by failing to adopt within sixty days of adjudication, and his purported sale of them after sixty days was invalid); In re Northern Ind. Oil Co., 180 F.2d 669 (7th Cir.), cert. denied, 340 U.S. 824 (1950) (trustee abandoned leases by failing to adopt them within statutory period); In re Pagliaro, 99 F. Supp. 548 (N.D. Cal. 1951), aff'd sub nom. Costello v. Golden, 196 F.2d 1017 (9th Cir. 1952).

58 Title Ins. \& Guaranty v. Hart, 160 F.2d 961, 965 (9th Cir.), cert. denied, 332 U.S. 761 (1947) ; In re M \& S Amusement Enterprises, 122 F. Supp. 364, 365 (D. Del. 1954). But see cases cited note 49 sipra. Section 102, 52 Stat. 883 (1938), 11 U.S.C. $\$ 502$ (1964), provides that the provisions of chapters I-VII apply to chapter X unless "inconsistent or in conflict" with the provisions of chapter X. That portion of $\$ 70 \mathrm{~b}$ held inapplicable is quoted in note 56 supra.

59 The same rule obtains for a chapter $X$ adoption. In the Matter of North Atlantic \& Gulf S.S. Co., 166 F. Supp. 29, 31-32 (S.D.N.Y.), aff'd sub nom. 120 Wall Associates v. Schilling, 266 F.2d 548 (2d Cir. 1959); In $r e$ Schulte Retail Stores Corp., 22 F. Supp. 612, 614-15 (S.D.N.Y. 1937). See also In the Matter of Walmer Screen Printing Co., 177 F. Supp. 684, 685 (E.D.N.Y. 1959). For a good explanation of this doctrine, see In re Chase Commissary Corp., 11 F. Supp. 288, 289 (S.D.N.Y. 1935). 
prior to any creditor's claims. ${ }^{60}$ The detriment to unsecured creditors in bankruptcy, whose claims can usually be satisfied only from liquid assets, is apparent. Reorganization, on the other hand, contemplates maintenance and rehabilitation of an operating business. ${ }^{61}$ Since ultimately profitable operations are expected to result from the reorganization, and creditors' claims must be fairly treated in the court-examined plan, pre-plan adoption in reorganization does not present the dangers of an adoption in straight bankruptcy. One would thus expect that in a reorganization, contracts and leases would be adopted by the trustee in order to prevent defaults and to maintain a competitive position; in straight bankruptcy the expectation is exactly the opposite, since all trustee activities point to termination and liquidation of the business. ${ }^{62}$

60 Section 64(a), 52 Stat. 874 (1938), as amended, 11 U.S.C. $\$ 104$ (a) (1964).

61 For cases drawing the same distinction, see Petition of Portland Elec. Power Co., 162 F.2d 618, 621 (9th Cir.), cert. denied, 332 U.S. 837 (1947); Consolidated Gas Elec. Light \& Power Co. v. United Rys. \& Elec. Co., 85 F.2d 799, 805 (4th Cir. 1936), cert. denied, 300 U.S. 663 (1937); In re Realty Associates Sec. Corp., 54 F. Supp. 787, 788 (E.D.N.Y. 1944). See note 40 supra.

It can be argued that, prior to a determination that reorganization can succeed, straight bankruptcy and reorganization both have straight bankruptcy characteristics, since the chapter $X$ attempt can easily wind up in bankruptcy, and should receive similar analysis with respect to these provisions until such determination is made. Cf. In re Neville Island Glass Co., 78 F. Supp. 508 (W.D. Pa. 1948). But cf. In re Public Ledger Inc., 161 F.2d 762 (3d Cir. 1947).

62 An opposite presumption in reorganization is confirmed by Consolidated Gas Elec. Light \& Power Co. v. United Rys. \& Elec. Co., 85 F.2d 799, 805 (4th Cir. 1936) :

Section 77B, on the other hand, does not contemplate the surrender and sale of the debtor's assets, but rather the transfer of the property, including executory contracts and leasehold estates not affirmatively rejected, to a reorganized body for the continuance of the business. An executory contract, therefore, renains in force in a proceeding under section $77 B$ until it is rejected, and unless rejected, it passes with other property of the debtor to the reorganized corporation.

(Emphasis added.)

And in contradistinction to chapter X's permissive trustee reporting requirements, note 15 sipra, straight bankruptcy's $\$ 70 \mathrm{~b}$ also requires the trustee to file a statement covering executory contracts he expects to reject. Note 56 silpra; see note 11 supra. If the bankruptcy trustee fails to do this, he may cause a loss to the estate, because of the automatic rejection provision. In re Gravure Paper \& Board Corp., 234 F.2d 928 (3d Cir. 1956) (automatic rejection held to occur despite sale of lease at public auction more than sixty days after adjudication). No such result can occur in chapter X.

In addition, consider the following comparison:

In a Chapter XI the contact between the court and the debtor is extremely close and the opportunity to exercise firm administrative control is unlimited. The entire structure of the Chapter is built on the continuation of the debtor in the possession of his property ....

Herzog, Reorganizations and Arrangements Under Chapters $X$ and XI: Problems of Administration Front the Standpoint of the Court, 35 REF. J. 113 (1961). The same writer draws the following sketch of the predominant characteristics of chapter X:

[Chapter X] represents a distillation of the experiences derived from all the earlier methods-common-law settlements, bankruptcy compositions, equity receiverships, and its immediate precursor, Section 77B. The point I seek to emphasize is that disinterested administrative assistance to the court is the keynote, and freed from the shackles of many purely administrative functions, the Judge can effectively perform his essential function, that is, to solve a complicated financial and legal problem, and to consider and compare the 
In conclusion, there is nothing in chapter $X$ which is inconsistent with reading sections $116(1)$ and $216(4)$ to allow the trustee to make the initial determination of an executory contract's disposition, and to require the trustee to seek court approval only when he rejects an executory contract, and thereby directly and immediately damages the interests of other parties. ${ }^{63}$

In support of its contention that adoption "should not be implied from the conduct of the trustee or debtor in possession, but should be the result only of judicial consideration," the Fifth Circuit in Texas Importing cited a footnote in Collier on Bankruptcy. ${ }^{64}$ The footnote cited states, in fact, that adoption should not be the result of inaction on the part of the trustee; it does not say that express trustee adoption, as in the Texas Importing case, is inconsistent with chapter $\mathrm{X}$ philosophy. Not only is the footnote inapposite, but its denial of the applicability of receivership practice is limited, and does not clearly include other aspects of estoppel or equitable doctrines in general. Further, Collier supports his contention that judicial consideration should be necessary for adoption with a single citation: the district court opinion in the case of In re Public Ledger Inc. ${ }^{65}$ Initially in a chapter $\mathrm{X}$ reorganization, the debtor was adjudicated a bankrupt several months after the initial petition for reorganization had been filed and approved. Two labor unions presented claims to the district court for money allegedly due their members because, during the few months of attempted reorganization, the trustee had allegedly adopted labor contracts which included provisions for vacation and severance pay. It happened that these contract provisions became effective during the reorganization, becoming in effect, a new contract arising during reorganization. The district court held that the trustees had never expressly adopted the contracts and stated that the contract could not have been adopted by the trustee without specific court

merits of various plans and approve for submission to creditors only those it finds to be fair and sound.

Id. at 117. (Emphasis added.) This is not to suggest that court supervision in chapter $X$ is not extensive. Compare 6 CollIER $\Uparrow 3.23$, at $575 \mathrm{n} .40$, discussed at text accompanying note 64 infra.

63 A wise trustee will of course seek court approval whenever relatively large sums of money are involved with respect to cash assets on hand. See note 8 supra. Cf. In re Schenectady Ry. Co., 93 F. Supp. 67, 69 (N.D.N.Y. 1950) :

Reorganization contemplates the control of the debtor's assets by the Court, and it would seem to follow that the Trustee could not make such obligation his own which might seriously encumber the assets without the consent and approval of the Court.

This is not to say that small contractual obligations could not be adopted without court approval. In fact, were the trustee required to petition the court and follow the procedure of hearings and court order for every adoption, the administrative process would be unnecessarily lengthened and made more costly. See note 14 sipra. The trustee will of course seek approval whenever the other party to the contract objects. See In re Childs Co., 64 F. Supp. 282 (S.D.N.Y. 1944), discussed at text accompanying notes $94-96$ infra.

64 6 Collier $\llbracket 3.23$, at 575 n. 40 .

65 63 F. Supp. 1008 (E.D. Pa. 1945), rev'd, 161 F.2d 762 (3d Cir. 1947). 
authorization-lacking court approval, had any express trustee adoption been attempted, it would be "invalid." 68 In support of this dictum the district court cited a straight bankruptcy case, ${ }^{67}$ authority inappropriate to chapter X.

Standing alone, the district court opinion is questionable atthority for Collier's proposition. Further, as noted by the Texas Importing court, Public Ledger was reversed on appeal. ${ }^{68}$ The Texas Importing court read the Public Ledger court of appeals opinion as holding that prior court authorization had been given to the trustee to adopt these contracts. But such was not the case. To be sure, the court of appeals in Public Ledger did cite the order of appointment instructing the trustee "to manage, operate and conduct the business ... and to employ and/or discharge, and fix the compensation of all employees . . . " 69 But this order is standard reorganization procedure; it is, in fact, nearly identical to the corresponding order in the Texas Importing proceedings. ${ }^{70}$ Such a court order merely authorizes trustee retention of the necessary work force and does not indicate "judicial consideration," the point for which it is cited.

Even more importantly, the provisions in the contract which the court of appeals held to have been adopted were not within the scope of the trustee's powers as enumerated by the court order of appointment: section 7 of the Public Ledger trustee's orders of appointment limited his authority to grant compensation to employees to "the paying of current wages." 71 Severance pay could not be considered "current wages"; in awarding severance pay, the court must have held the contract to have been adopted without prior court approval.

Not only did the Texas Importing court misread Public Ledger, but it ignored paragraphs of that opinion which specifically referred to adoption of executory contracts implied from trustee conduct. The court of appeals in Public Ledger quoted with approval the definitions of "adoption" contained in a law review article on receiver's adoption and rejection of executory contracts. ${ }^{72}$ One quoted definition reads:

6663 F. Supp. at 1016.

67 Erie Malleable Co. v. Standard Parts Co., 299 Fed. 82 (6th Cir. 1924).

68 In re Public Ledger Inc., 161 F.2d 762 (3d Cir. 1947).

69 Id. at $764,766$.

70 That the Trustee appointed herein be and he is hereby authorized and directed, subject to such supervision and control by this Court as this Court may exercise by further Orders herein, to conduct the business and manage, maintain and keep in proper condition and repair, the assets, properties, and business of the Debtor, wherever situated; and to employ and discharge and to fix the compensation of all managers, superintendents, agents, servants and employees ...

Record, p. 31, Texas Importing Co. v. Banco Popular de Puerto Rico, 360 F.2d 582 (5th Cir. 1966) [hereinafter cited as Record].

7163 F. Supp. at 1012 n.7.

72 Clark, Foley \& Shaw, supra note 31. 
[Adoption is] "a situation in which a receiver . . . acts in such a way with reference to a contract . . . that fairness to the solvent party requires that the consequences of adoption be attributed to his action." 73

The court of appeals in Public Ledger also quoted from the same article that " some action by [a] receiver may be held to amount to adoption despite an intention to the contrary." "74 The court in Texas Importing also ignored a footnote in the Public Ledger opinion in which the court quoted section 70 (b) of chapter VII, ${ }^{75}$ not then held inapplicable to chapter $\mathrm{X}$, and continued:

It should be noted that the act does not specify the manner of acceptance of an executory contract . . . . Acceptance may be by conduct as well as by writing or oral statement. ${ }^{76}$

The court of appeals in Public Ledger specifically reversed the entire district court decision, and held that the trustees had adopted the contract, not expressly, but by conduct implying adoption. ${ }^{77}$ The final decree demanded full compliance with the contract's terms during the time the parties acted in adherence thereto. The court of appeals' decision in Public Ledger correctly applied equitable principles consistent with the facts presented and does not support the proposition for which it was cited in Texas Importing.

The Public Ledger decision is even more noteworthy, however, because of the final adjudication of bankruptcy. ${ }^{78}$ By holding vacation and severance pay ("a considerable sum" 79) to be an expense of administration, the claims of the unsecured creditors in Public Ledger must have been severely prejudiced. No such severe effects would

73 In re Public Ledger Inc., 161 F.2d 762, 767 (3d Cir. 1947).

74 Ibid.

75 See note 58 supra and accompanying text. It should be noticed that the application of $\$ 70 \mathrm{~b}$ to the reorganization then before the Public Ledger court of appeals reads additional court supervision into reorganization procedure. A court faced with facts suggesting trustee adoption without "judicial consideration" after $\$ 70 \mathrm{~b}$ was held inapplicable, can rely with even greater certainty upon Public Ledger for the proposition that binding adoption can be "implied" from trustee actions. The more complete separation of straight bankruptcy from reorganization yields greater flexibility for trustee handling of the debtor's business contracts and leases. It also means that courts should be more willing to apply equitable considerations to chapter $\mathrm{X}$ adoptions.

$76161 \mathrm{~F} .2 \mathrm{~d}$ at 765 n.1. (Emphasis added.). Cf. In re Italian Cook Oil Corp., 190 F.2d 994, 996-97 (3d Cir. 1951). Trustees in chapter X reorganization petitioned to reject debtor's assignment to bank of expected proceeds from contract to sell mayonnaise. At the time of this petition, the trustees had gone ahead with the manufacture and delivery of mayonnaise. The court held that this amounted to assumption of the contract. See In re Forgee Metal Prods., Inc., 229 F.2d 799 (3d Cir. 1956), discussed at note 56 supra.

$77161 \mathrm{~F} .2 \mathrm{~d}$ at 767.

$78 \mathrm{Id}$. at 765 .

$79 I d$. at 771 . 
have followed had adoption been found in Texas Importing. ${ }^{80}$ Despite the hardship to unsecured creditors, the court in Public Ledger did hold severance pay to be owed to the unions by the then bankrupt corporation, in effect a finding of binding adoption even though implied. Read carefully, then, Public Ledger indicates not only that equitable considerations are as applicable to chapter $\mathrm{X}$ as they were to section 77B and equity receiverships, but that, had those considerations been properly applied in Texas Importing, adoption could have been found in that case even more easily than in Public Ledger.

In re Schenectady $R y .^{81}$ was also cited by the Texas Importing court as direct support for its contention that the doctrine of estoppel should not be applied to chapter X adoption of contracts. Schenectady dealt with a labor contract which required "the debtor to make pension payments during the balance of the lives of the pensioned employees." 82 The question before the court was whether the debtor was required to make any of those payments to the petitioning unions. The record, noted the court, was "entirely silent as to affirmative action on the part of the trustee which would indicate that the labor contract had been adopted . . ." ${ }^{83}$-a fact which makes this case distinguishable from Texas Importing. The opinion implied that it considered judicial approval necessary for adoption by noting the trustee's failure to petition the court. But the court continued:

While Chapter 10 lays down a scheme for the conduct of affairs of financially embarrassed corporations to the end that the going value of the assets may be preserved, reorganization has its practical aspects and the statutory scheme does not entirely foreclose them. [The court then found that the trustee had neither affirmed nor rejected the contract.]

No judicial decision is cited which might be termed a precedent in this case and it would seem that the determination of the question would depend upon the particular facts involved. Equitable considerations dictate that under the circumstances existing in this case the payment of the monthly pensions are a part of operating expenses and as such should be paid by trustee during that period that the parties knowingly conform to the contract. ${ }^{84}$

Two factors in the decision should be noticed: the case was decided upon equitable grounds (even though the facts did not reveal any

so See text accompanying notes 59-62 supra.

8193 F. Supp. 67 (N.D.N.Y. 1950).

S2 Id. at 69 .

83 Ibid.

84 Id. at 70. (Emphasis added.) 
intention to adopt), and the court let the intentions of the parties control the effect to be given the contract. Both of these considerations indicate that Schenectady would dictate a contrary result in Texas Importing; they illustrate little concern with a need for judicial consideration.

A case unnoticed by the Texas Importing court is Black $v$. Richfield Oil Corp., ${ }^{85}$ in which reorganization proceedings were held under section 77B. The defendant, Richfield, had purchased a reorganized company through a plan in which Richfield agreed to assume some existing liabilities acquired through the reorganization trustee, "including such contracts as had been assumed by the Court." 86 The plaintiff alleged that a licensing agreement had been omitted from a contract which, it further alleged, was held by the reorganized company. However, the disputed contract was "never affirmed by the court and was never specifically assumed under the reorganization agreement." 87 The court concluded:

The evidence clearly indicates that the trustee clearly recognized the agreement and the conduct of the defendant corporation establishes that it too assumed the said licensing agreement had been affirmed by the court and that they were bound by the terms of the same. For the purposes of this opinion, I have acted on the assumption that the new corporation specifically assumed the said agreement and is bound by the terms thereof, to the same force and effect as if the said agreement had been specifically affirmed by the court in accordance with the usual procedure under $\S 77 \mathrm{~B} .^{88}$

The reference to the "usual procedure" is unclear. It no doubt refers to the usual catch-all provision in a plan whereby all executory contracts are adopted, and a few enumerated contracts are rejected, as was done in the Texas Importing proceedings. ${ }^{89}$ In any event, the absence of adherence to the "usual procedure" did not prevent the court from holding the parties to a contract which had not received judicial consideration, but was considered adopted by the contracting parties.

8541 F. Supp. 988 (S.D. Cal. 1941), aff'd, 146 F.2d 801 (9th Cir.), cert. denied, 325 U.S. 867 (1945).

$86 I d$. at 991.

87 Ibid.

88 Id. at 991-92. (Emphasis added.)

89 All executory contracts shall be accepted by the Continuing and Reorganized Company, with the exception of the real property lease upon the premises occupied by the home office of the Debtor, ... wherein Atlas Sewing Centers, Inc., is the Lessee, and the Texas Importing Company is the Lessor. This executory contract shall be rejected

Record, pp. 60-61. Accord, In re American R.R., 110 F. Supp. 45 (D.P.R. 1952), aff'd, 202 F.2d 149 (2d Cir. 1953) ; cf. Mohonk Realty Corp. v. Wise Shoe Stores, 19 N.Y.S.2d 981, 984 (Sup. Ct. 1940), rev'd on other groninds, 260 App. Div. 64, 20 N.Y.S.2d 739, appeal dismissed, 286 N.Y. 476, 36 N.E.2d 669 (1941). 
In conclusion, there is case authority for finding binding adoption even where there is no court consideration of the executory contract. Further, numerous courts have searched the facts before them for evidence of estoppel, implying in several instances that estoppel could arise on a set of facts stronger than those before them. ${ }^{90}$ Equitable considerations have consistently been used in reorganization and should continue to be applied to the trustee's administration.

As the basis of its finding that the lease was not legally assumed, the Texas Importing court held that, to be effective, trustee adoption requires court approval. In support of this contention it cited three cases: In re Schenectady $R y .{ }^{91}$ In re Childs $C o .^{92}$ and In re Walker. ${ }^{93}$ Schenectady, as noted earlier, is equivocal on this point. Although the court said that no rejection or adoption took place under its facts, the contract was given full effect for the period of time that both parties adhered to it.

In re Childs dealt with petitions filed by a landlord seeking termination of leases held by the debtor; the trustee cross-petitioned for approval to assume the leases. One of the grounds upon which the landlord relied was trustee disaffirmance of the leases through his attorney. The court held that statements of an intention to reject unless the rent were lowered constituted "arm's-length negotiations"; it found that "the facts relied upon are not strong enough for me to say that the Trustee is estopped from coming to Court and asking authority to assume the leases." 94

However, the Childs court interpreted section 77B practice to require court authorization of trustee adoption as well as rejection. This is simply incorrect. ${ }^{95}$ The court's conclusion that chapter X's section $116(1)$ should be interpreted in the same way as was section

${ }^{80}$ In re Chicago Rapid Transit Co., 129 F.2d 1, 7 (7th Cir.), cert. denied, 317 U.S. 683 (1942) (facts fell short of showing estoppel, trustee dissatisfaction exhibited within five months); Hotz v. Federal Reserve Bank, 108 F.2d 216 (8th Cir. 1939); In re Rochester Shipbuilding. Co., 32 F. Supp. 98, 100-01 (W.D.N.Y. 1940) (facts insufficient because no clear intention to adopt, trustee acting within a "reasonable insufficient because no (ime Chicago Rapid Transit Co., 129 F.2d 1, 9-11 (7th Cir. 1942) (Evans, J., dissenting) (facts did show adoption).

9193 F. Supp. 67 (N.D.N.Y. 1950).

0264 F. Supp. 282 (S.D.N.Y.), aff'd sub nom., 415 Fifth Ave. Co. v. Finn, 146 F.2d 592 (2d Cir. 1944).

9393 F.2d 281 (2d Cir. 1937). In re M \& S Amusement Enterprises, Inc., 122 F. Supp. 364 (D. Del. 1954), also cited by the Texas Importing court, presents similar issues in reverse: the debtor is petitioning to reject a contract. Consequently the case falls squarely within the Cheney rationale, note 37 sipra, and cannot be considered authority on the question of adoption.

$9464 \mathrm{~F}$. Supp. at 287. As the Childs court itself noted, this examination of the facts was rendered "more or less moot" by the trustee's statutory limitation: "In as much as the Trustee did not have the power to reject a lease, I doubt very much that his acts and declarations would have the effect of rejection." Id. at 286.

95 See note 37 sipra. Curiously enough, the Texas Importing court relies upon the Childs case which misread the Cheney case, even though the Texas Importing court itself correctly applies the Cheney case. $360 \mathrm{~F} .2 \mathrm{~d}$ at 584. 
$77 \mathrm{~B}$ (c) (5) is entirely correct, but the conclusion should have been that case authority under section $77 \mathrm{~B}$ requires court consideration only of rejection. Even though the court appears to fail to perceive a rather basic distinction, ${ }^{96}$ and even if its misreading of section $77 \mathrm{~B}$ were conceded, there is no reason to suppose that Childs is authority for requiring court approval for adoption, since the trustee, desiring to retain the lease, had no choice but to seek the court's assistance. He had already been dragged into court by a lessor who wanted to terminate the lease; approval to adopt was the trustee's defense and counterclaim. Any statements by the court indicating a requirement of court approval are clearly dicta.

Another case cited by the Texas Importing court which states that adoption without court approval is ineffective is In re Walker. ${ }^{97}$ That case concerned the right of a landlord to dispossess the debtor pursuant to provisions in a lease granting the lessor a right of reentry upon several conditions subsequent; insolvency and devolution of title were two of the conditions held to be satisfied. The question of lessor waiver of that right arose because he had accepted payments from the trustee for use of the premises during the "reasonable time" of the trustee's early administration. The court could have decided the case on a close examination of the record-there was no expression of an intention to adopt, no expression of lessor waiver of the right of reentry. The cases hold that trustee payment of a reasonable sum of money, an expense of administration, for "use and occupation" is required of the trustee using premises under lease, up until such time as he elects to adopt or reject. ${ }^{98}$ (The consequences of rejection have been set out above. ${ }^{99}$ ) If he adopts, the terms of the lease must be

96 While the court clearly has jurisdiction to decide disputes between the trustee and lessor-it is, to be sure, the court which has "the last say," 64 F. Supp. at 286, on any disagreement over adoption-that is not the same thing as invalidating a consensual agreement to continue the lease merely because that adoption did not receive judicial consideration. The court's power and jurisdiction to decide disputes over adoption should not be confused with a sweeping court requirement that such jurisdiction alzways be invoked by the trustee even where there is no disagreement over whether the lease should be, or can be, adopted.

97 93 F.2d 281 (2d Cir. 1937).

98 In the Matter of North Atlantic \& Gulf S.S. Co., 166 F. Supp. 29, 31-32 (S.D.N.Y. 1958), aff'd sitb nom., 120 Wall Associates v. Schilling, 266 F.2d 548 (2d Cir. 1959) ; In re Schulte Retail Stores Corp., 22 F. Supp. 612, 614-15 (S.D.N.Y. 1937). See also In the Matter of Walmer Screen Printing Co., 177 F. Supp. 684, 685 (E.D.N.Y. 1959). For a good explanation of this doctrine, see In re Chase Commissary Corp., 11 F. Supp. 288, 289 (S.D.N.Y. 1935).

As in equity receiverships, the "reasonable time" rule would appear to be applicable to chapter X adoption since an executory contract can be rejected in the plan, often a considerable length of time from the time of petition-filing. But see In re Schulte Stores Corp., 22 F. Supp. 612, 614-15 (S.D.N.Y. 1937).

Rejections are more closely watched by the courts:

In bankruptcy reorganizations, the initial orders generally expressly preserve the right of rejection and prescribe a period, usually six months, within which it may be exercised. Extensions are frequently granted for further periods.

In re Chicago Rapid Transit Co., 129 F.2d 1, 7 (7th Cir.), cert. denied, 317 U.S. 683 (1942).

99 Text accompanying note 15 supra. 
complied with, i.e., the estate is liable for full rent from the time of petition approval until the corporation is finally reorganized. ${ }^{100}$ The facts of $W$ alker place it squarely within the line of decisions so holding; the case could have been disposed of by a close examination of trusteelessor intentions. ${ }^{101}$ But Judge Learned Hand went further and stated that a trustee "is forbidden to affirm the lease without order of the court, and the payment of rent as rent would be as much an affirmance, if lawful, as is the lessor's acceptance." 102

The Texas Importing court accepted this statement without any examination of the clear factual distinctions between Texas Importing and Walker. There was no express adoption in Walker, merely payment of money due for use of the premises, which trustees are obligated to pay. Waiver was asserted against the lessor for acceptance of money for four months, a "reasonable" length of time showing no trustee intention to adopt under established case law; in Texas Importing, estoppel was asserted against the trustee for payment of less than full rent for twenty months, clearly not a "reasonable" length of time in view of both the express adoption and the deadline set for a tentative plan by the Texas Importing court. ${ }^{103}$ Walker does not

100 See cases cited note 98 suspra.

101 Just such an approach was taken in $I n$ re Schulte Retail Stores Corp., $22 \mathrm{~F}$. Supp. 612 (S.D.N.Y. 1937), where the lessor also petitioned to dispossess. The debtor contended that acceptance of one month's payment of rent constituted a waiver of the lessor's right to re-enter since such right had by then expired under the terms of the lease. In granting the lessor's petition, the court said:

When property of a... [lessor] is thus put to use of a distressed debtor, and the price of its use is capable of being called either rent or payment for use and occupation, it should not lie wholly within the power of the debtor to make choice of the denominating quality.... [I] $u$ the absence of clear and convincing proof that the lessor intended to waive the breach in the lease, it should not be considered to have done so.

$I d$. at 615 . (Emphasis added.) For other cases clearly placing upon the trustee the burden of initiating action with respect to the lease, see Hotz v. Federal Reserve Bank, 108 F.2d 216, 219 (8th Cir. 1939); Consolidated Gas Elec. Light \& Power Co. v. United Rys. \& Elec. Co, 85 F.2d 799, 805 (4th Cir. 1936), cert. denied, 300 U.S. 663 (1937). See also Moore v. Risley, 287 Fed. 10, 13 (9th Cir. 1923), for a set of facts similar to Childs where a receiver, contrary to the referee's expectations, did try to take advantage of the lessor-equity prevailed.

10293 F.2d at 283 . The latter part of Judge Hand's statement, though admittedly obscure, can probably be taken to mean that if court approval is required to make an adoption binding, payment of rent by the trustee could never, by itself, constitute an adoption of the contract. And if payment of rent by the trustee could not, without court approval, constitute adoption, neither could acceptance by the lessor.

103 Under the orders of appointment, the trustee was instructed to report to the court by August 24,1962, "as to the advisability" of any adoption or rejection of executory contracts held by the debtor. The record, noted the court, without explanation as to why notice was taken of that fact, failed to disclose any compliance therewith. However, under $\S 12$ of the orders, the trustee was directed "to formulate and present a proposed plan of reorganization to this Court by August 24, 1962"-the same date on which the report on executory contracts was due. It can thus be inferred that by August 24-two months after the petition was filed-the court expected to be able to decide whether reorganization was feasible. Trustee ratification of the lease occurred in a letter dated September 20, 1962-a month after the court should have known whether to proceed with reorganization. There is no evidence in the record of any extension of the time limit for submission of a tentative plan; nor is there any evidence that such a determination could not have been made, or for that matter, was in fact made, by the specified time. The only clear inference to be drawn 
treat the same problem as was presented to the Texas Importing court and should not have been considered controlling.

A factor ignored by the Fifth Circuit is that both parties to the lease considered it to have been adopted. The acceptance of less than full rent under the lease is easily viewed as a sign of lessor cooperation. $^{104}$ One case specifically dealt with a cooperative lessor who reduced the monthly rental upon a receiver's adoption of the lease. ${ }^{105}$ The court there found an added equity for allowing lessor collection of the full rent for the term of the lease where the trustee abandoned and did not use the premises during the later months of the reorganization proceedings. And, in a state equity receivership, a lessor was given a preferred claim for a part of the back rentals allowed to accumulate because of his and other creditors' cooperation with the debtor. ${ }^{106}$ It follows from all that has been said that the very least the Texas Importing court could have done was to make provision in the plan for full rent during the two years of trustee-lessor adherence to the contract.

It may be that the Texas Importing court was presented with facts which raised doubts about the cleanliness of the lessor's hands. ${ }^{107}$

is that any possible trustee failure to report on executory contracts did not impede the reorganization proceedings, and should carry little weight in deciding the case. Cf. Hotz v. Federal Reserve Bank, 108 F.2d 216, 220 (8th Cir. 1939); Consolidated Gas Elec. Light \& Power Co. v. United Rys. \& Elec. Co., 85 F.2d 799, 801 (4th Cir. 1936), cert. denied, 300 U.S. 663 (1937).

The plan which called for the lease's rejection was filed on May 8, 1964. Record, p. 40. Thus the lessor, who had been notified on September 20, 1962, that its lease with the debtor was considered ratified, was misled for nearly twenty months. There is little doubt that the elements of equitable estoppel are present:

The vital principle is that he who by his language or conduct leads another

to do what he would not otherwise have done, shall not subject such person

to loss or injury by disappointing the expectations upon which he acted. . . .

This remedy is always so applied as to promote the ends of justice.

Dickerson v. Colgrove, 100 U.S. 578, 580 (1880). See cases cited note 101 supra.

The trouble with the court's conclusion that the lessor can always force an election through petition to the court, $360 \mathrm{~F} .2 \mathrm{~d}$ at $584-85$, is that it ignores the essential facts of the case before it: the lessor had already been assured that its lease with the debtor was considered worth retaining. The lessor was thereby effectively precluded from initiating any more aggressive action he might have taken had he thought his lease was of doubtful value to the estate.

104 There is an unexplained sentence in the court's opinion that the lessor, during the trustee's administration, accepted less money from the debtor-lessee than was called for under the lease. While the record sheds no light on this statement, such an arrangement is often employed by helpful creditors to assist the debtor to regain its fiscal balance. It is hard to believe that this fact could have influenced the court in reaching its decision, unless it knew facts which it failed to mention.

105 Hotz v. Federal Reserve Bank, 108 F.2d 216, 219 (8th Cir. 1939).

106 Andrews v. Beigle, 6 Ohio App. 427, 434 (1915). State equity proceedings are not binding upon federal courts adjudicating proceedings under the Bankruptcy Act, Petition of Portland Elec. Power Co., 162 F.2d 618, 621 (9th Cir.), cert. denied, 332 U.S. 837 (1947), but the case is illustrative of one court's handling of the problem.

107 It is not clear whether the lessor was merely a dummy corporation holding rental properties for the debtor. The amended plan of August 4, 1964 stated:

The basis of this rejection is simply that Texas Importing Company, Ltd., acquired the said property as the alter ego of the debtor and an effort to determine this contention will be made and if said claims are proven to the satis- 
If that were the case, the inequities should have been discussed and elucidated. Whatever the court's motivation, Texas Importing yields an abstract rule of procedure which cuts against the hoped for cooperation between creditors and the debtor. It unnecessarily lengthens the administration of the estate with its requirement of hearings and continual trustee reference to the court, and it reduces the overall flexibility of trustee administration and increases costs.

The following alternative method of treating trustee adoption is proposed. At the time the approved plan calling for the rejection of a lease (or contract) already adopted by the trustee is presented for confirmation, these two questions should be asked:

(1) Was the adoption, at the time it was effectuated by the trustee, the result of a sound business decision, or did the trustee fail to fulfill his fiduciary obligation? ${ }^{108}$

(2) Did both parties consider the lease adopted, and were its agreed-upon terms then considered binding by them? ${ }^{109}$

If the answers to both questions are positive, then the court is precluded from allowing the lease's rejection. If the parties considered it adopted and binding, but sound business judgment was not then exercised, the trustee's adoption is effective only to the date of the contemplated rejection in the plan; full rent must be paid as "an expense of administration" from adjudication to plan confirmation. If the lease had looked profitable when adopted, a change in business circumstances

faction of the Court then in that event the real estate involved will become an asset of the Continued and Reorganized Company.

Record, pp. 86-87. (Emphasis added.)

In addition, two persons were appointed to draw up the reorganization plan-the trustee and counsel for the debtor. Somehow the trustee allowed a plan to be drafted which reversed his ratification of the lease made twenty months earlier (the final plan was submitted May 8, 1964).

Further muddying the waters is the unexplained sentence in the court's opinion, referred to in note 104 supra, noticing that the Iessor accepted less than full rent during administration. The negative implication which arises could be rebutted, if the court so chose and the facts were consistent, as is suggested in that footnote.

${ }^{108}$ Cf. In re Public Ledger Inc., 161 F.2d 762, 771 (3d Cir. 1947) :

At any rate the trustees' action in assuming the contract obligation was taken in good faith and according to their best judgment and must be held to have been a necessary expense in administering the estate and is entitled to priority as an administration expense.

(Emphasis added.) While this proposed question might seem an unnecessary ad hoc determination which could be avoided by merely requiring the trustee to gain advance approval of the court it is suggested that such a requirement is inappropriate and unnecessary. See note 56 supra.

It is also desirable to avoid determining whether the executory contract was one which the trustee should have brought to the court. Such a question is beside the point at the time of plan confirmation. The trustee's judgment should be respected in so far as he has fulfilled his fiduciary obligation to exercise sound business judgment; when he acts without exercising such judgment, or good faith, he is acting ultra vires.

$109 \mathrm{Cf}$. text accompanying notes $73,77,84,88$ supra. 
should not enable the court to permit the trustee to change his mind. ${ }^{110}$ This approach would have enabled the Texas Importing court to search the record and find, if it were true, that trustee-counsel communications had broken down and that the lease was always unprofitable, or that a questionable arrangement had been consummated. The court could then have found no equitable consideration sufficient to outweigh the need for the lease's rejection in the plan. Some measure of certainty in creditor relations is necessary, but it needs to be balanced with the need for speed and flexibility so important to a successful reorganization.

110 Cf. Grief Bros. v. Mullinux, 264 Fed. 391 (8th Cir. 1920); In re Davega Stores Corp., BANKR. L. REP. \60777 (S.D.N.Y. 1963), discussed at note 47 sipra. 